\title{
T. S. Eliot y la cultura española: entre la Tierra baldía y las Soledades de Góngora
}

\author{
MARGARITA GARBISU
}

Universidad a Distancia de Madrid, UDIMA

\begin{abstract}
Resumen
El presente artículo pretende dar a conocer la intervención de T. S Eliot en el proceso de publicación de las primeras traducciones al español y al inglés, respectivamente, de dos textos líricos fundamentales: The Waste Land, del propio Eliot, y Soledades, de Luis de Góngora. En el caso del poema eliotiano, en 1930 surgieron dos versiones a cargo de Ángel Flores y de Enrique Munguía; en el caso de las Soledades, publicadas en 1931, la traducción fue realizada por Edward Meryon Wilson. Eliot trató de contribuir a que las tres versiones vieran la luz, circunstancia que ahora se conoce mejor gracias a la información aportada por sus epistolarios, que en los últimos años se están publicando. Este episodio, enmarcado entre finales de los años veinte y principio de los treinta, se convierte en una nueva aportación al marco de la relación anglohispánica y al vínculo de Eliot con la cultura española.
\end{abstract}

\begin{abstract}
The aim of this article is to bring to light the role that T. S Eliot played in the process of the publication of the first translations into Spanish and English, respectively, of two fundamental lyrical texts: The Waste Land, by Eliot himself, and The Solitudes, by Luis de Góngora. Two versions of Eliot's poem were published in 1930: by Ángel Flores in Spain and by Enrique Munguía in Mexico; the translation of The Solitudes was carried out by Edward Meryon Wilson and published in 1931. Eliot attempted to intercede in the publication of these translations, a fact now revealed thanks to the recent publication of his correspondence. This episode, which took place between the late 1920s and early 1930s, becomes a new contribution to the relationship between the English and Spanish cultures and the link between Eliot and Spanish culture.
\end{abstract}

En los últimos años la figura de Thomas Stearns Eliot se encuentra mucho más al alcance de lectores e investigadores ya que se está publicando paulatinamente su correspondencia. Hasta mediados de 2015 han visto la luz los cinco primeros volúmenes de sus cartas, que abarcan el periodo 1898-1931, esto es, entre los 10 y 